\title{
Lack of correlation between Ki-67 labelling index and tumor size of anterior pituitary adenomas Luciano Mastronardi $^{* 1}$, Antonio Guiducci ${ }^{1,2}$ and Fabrizio Puzzilli ${ }^{1}$
}

Address: ${ }^{1}$ Division of Neurosurgery, Sandro Pertini Hospital, Roma, Italy and ${ }^{2}$ Institute of Pathological Anatomy, Civilian Hospital, Terni, Italy E-mail: Luciano Mastronardi* - mastro@tin.it; Antonio Guiducci - guiduccia@aospterni.it; Fabrizio Puzzilli - fpuzzilli@tiscalinet.it ${ }^{*}$ Corresponding author

Published: 21 August 200I

BMC Cancer 200I, I:12
Received: I May 2001

Accepted: 21 August 2001

This article is available from: http://www.biomedcentral.com/I47I-2407/I//2

(c) 200I Mastronardi et al; licensee BioMed Central Ltd. Verbatim copying and redistribution of this article are permitted in any medium for any noncommercial purpose, provided this notice is preserved along with the article's original URL. For commercial use, contact info@biomedcentral.com

\begin{abstract}
Aims and background: The Ki-67 is a nuclear antigen detected by the monoclonal antibody MIB-I and its Labeling Index (LI) is considered a marker of normal and abnormal cell proliferation. Pituitary adenomas are generally well differentiated neoplasms, even if in about one third of cases they are invasive of surrounding tissues. The aim of this study is to evaluate the correlation between $\mathrm{Ki}-67$ labelling index and tumor size of pituitary adenomas extimated by means CT and MRI and confirmed at operation.
\end{abstract}

Methods: Using the monoclonal antibody MIB-I, we evaluated the expression of Ki-67 in I2I anterior pituitary adenomas consecutively operated on in a 48-month period.

Results: In relation to neuroradiological (CT and MRI) and surgically verified tumor size, we identified 24 microadenomas, 27 intrasellar macroadenomas, 34 intra-suprasellar macroadenomas, and 36 intra-supra-parasellar macroadenomas. The adenomas were non-infiltrating (76 cases) and infiltrating (45 cases) adenomas. The wall of the cavernous sinus (CS) was infiltrated in 18 cases. Forty-eight adenomas were non-functioning and 73 functioning. The overall mean \pm SD Ki-67 LI was $2.72 \pm 2.49 \%$ (median 1.6). It was $2.59 \pm 1.8 \mathrm{I}$ in microadenomas, $2.63 \pm 3.45$ in intrasellar macroadenomas, $1.91 \pm 2.11$ in intra-suprasellar macroadenomas, and $3.29 \pm 5.45$ in intra-supraparasellar macroadenomas $(p=0.27)$. It was $3.73 \pm 5.13 \%$ in infiltrating and $2.03 \pm 2.41 \%$ in noninfiltrating adenomas $(p=0.02)$, and $5.61 \pm 7.19 \%$ in CS-infiltrating versus $2.09 \pm 2.37 \%$ in CS-noninfiltrating adenomas $(p=0.0005)$.

Conclusions: Our preliminary results seem to exclude significative correlations between $\mathrm{Ki}-67$ $\mathrm{LI}$ and tumor size of anterior pituitary adenomas, even if this index can be considered a useful marker in the determination of the infiltrative behaviour of these tumors.

\section{Introduction}

Anterior pituitary adenomas have usually considered benign tumors, even if in about $1 / 3$ of cases they infiltrate surrounding tissues, including the wall of cavernous sinus (CS) $\left[1,2,4-7,18-20,23,25^{-27,30}\right.$. This local "malignancy" contributes to explain the possibility of relapse even after a macroscopically total surgical excision of tumor. As observed for other neoplasms, the determination of cell proliferation activity seems to be useful in making prognosis also in anterior pituitary adenomas. In particular, Ki-67 is a nuclear antigen expressed in the $G_{1}$, $S, \quad G_{2}$, and $M$ phases of cellular cycle 
$[17,21,22,24,29,32,34]$ and its Labeling Index (LI), nowadays recognizable by means the monoclonal antibody MIB-1 [21], is widely considered as a marker of cellular proliferation (growth fraction).

The aim of this study is to investigate the relationship between proliferative activity of anterior pituitary adenomas, quantified with $\mathrm{Ki}-67 \mathrm{LI}$, and their size neuroradiologically (CT and MRI) and surgically verified.

\section{Materials and Methods \\ Patient characteristics}

From July, 1994, to July, 1998, 121 patients suffering from an anterior pituitary adenoma were consecutively operated on. In all cases an evaluation of the the Ki-67 LI of surgical specimens was performed by means the monoclonal antibody MIB-1 [21].

The age ranged from 17 to 77 years (mean $43.1 \pm 15.5$, median 40 ). The $\mathrm{M} / \mathrm{F}$ ratio was $1: 1.42$ ( 71 females and 50 males). In 21 cases one previous operation and in 2 cases two previous operations for the treatment of the pituitary adenoma had been performed elsewhere (total 23 cases). A functioning adenoma, with clinically expressed hormonal dysfunction, was present in 69 patients (59.5\%): in $29(42.0 \%)$ disturbances related to high level of serum PRL were detected, in 28 (40.6\%) acromegaly was diagnosed, and in 12 (17.4\%) Cushing's disease was observed. One patient had high pre-operative levels of FSH, without correlated clinical symptoms and sign. The preoperative hormone serum level was defined as the highest value observed before surgery. Visual acuity and/or campimetric disturbances were present in 55 cases (45.5\%). An intracranial hypertension syndrome was observed in 6 cases $(5.0 \%)$.

In all cases the neuroradiological diagnosis was obtained using both contrast-enhanced cerebral CT scan and MRI. In relation to the tumor size, the adenoma was considered: A) microadenoma ( $\leq 10 \mathrm{~mm}$ in diameter), 24 cases (19.8\%); B) intrasellar macroadenoma, 27 cases (22.3\%); C) intra-suprasellar macroadenoma (with extension above the sella turcica), 34 cases (28.1\%), and D) intrasupra-parasellar macroadenoma (with extension above the sella and toward the cavernous sinus), 36 cases (29.7\%). The tumor size was confirmed in all cases by the impression of surgeon at operation.

A transsphenoidal approach was used in 116 cases (95.9\%), whereas a craniotomy was performed in 5 cases (4.1\%). In 113 cases (93.4\%) a macroscopically total removal and in 8 (6.6\%) a subtotal excision of tumor was obtained. In relation to surgically verified infiltration of sellar floor dura and bone, we identified 76 (60.3\%) non- infiltrating and $45(39.7 \%)$ infiltrating adenomas. The wall of cavernous sinus was infiltrated in 18 out of 45 cases (14.9\% of 121 total cases and $40.0 \%$ of 45 infiltrating cases). Histological examination showed in all cases a typical anterior pituitary adenoma. On the basis of immunohistochemical staining we recognized 48 (39.7\%) endocrine-inactive and 73 (60.3\%) active adenomas (26 PRL, 24 GH, 12 ACTH, 7 mixed, 3 TSH, and 1 FSH). Plurihormonal adenomas were classified according to the predominant endocrine symptoms (in 4 cases GHand in 3 PRL-related disturbances). Twenty out of 29 patients $(68.9 \%)$ with prolactinomas or with mixed adenoma with prevalent PRL expression received preoperative medical therapy (bromocriptine).

\section{Determination of the Ki-67 Labeling Index (MIB-I immu- nostaining)}

The surgical specimens were routinely processed, fixed in neutral buffered formalin, and embebbed in paraffin. In order to evaluate the Ki-67 antigen staining, 5-micrometer sections, previously mounted onto glass slides and dried, were incubated overnight at $4^{\circ} \mathrm{C}$ in the MIB-1 antibody (Immunotech, Marseille, France) [21]. Immunostaining was performed using the avidin-biotin-peroxidase method. Ten fields were selected in regions with highest concentrations of MIB-1-positive nuclei and were examinated at high power magnification (x400). Each field corresponded to a total number of cells ranging from 700 to 1000 , in relation with the cellularity of the tumor specimen (Fig. 1). Areas of necrosis, normal adenohypophysial cells, and endothelial cells were exluded from the evaluation. On considering 1000 cells with "manual" counting, the Ki-67 Labeling Index has been defined as the percentage of MIB-1 positive cells (dense brown precipitate restricted to the nuclei).

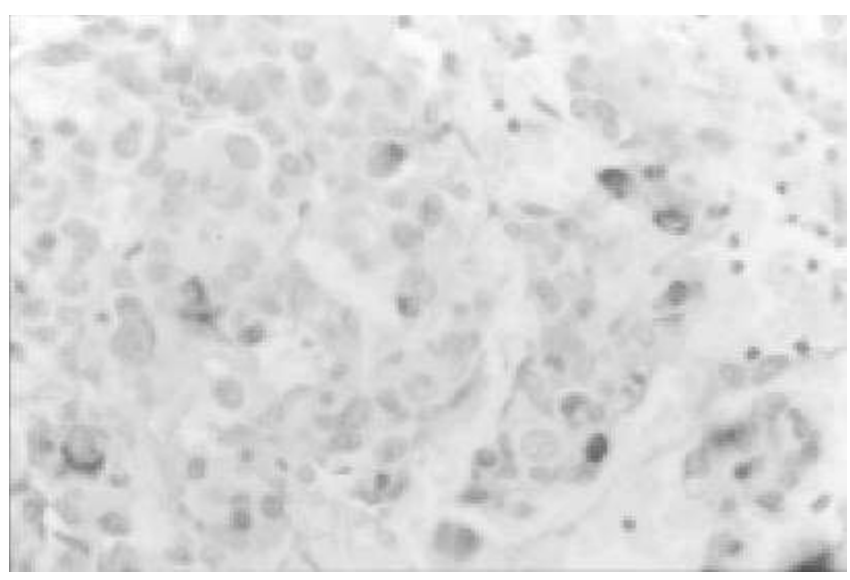

Figure I

MIB-I immunostaining of a mixed (GH-PRL) infiltrating pituitary adenoma (original maginification, $\times 400$ ). A high proportion of labeled nuclei are seen $(\mathrm{Ki}-67 \mathrm{LI}=10 \%)$. 
Table I: Mean Ki-67 LIs of I 2 I anterior pituitary adenomas.

\begin{tabular}{|c|c|c|c|}
\hline & N. of cases & Mean LI (\%) & $P$ \\
\hline All patients & 121 & 2.72 & \\
\hline Visual disturbances: yes & 47 & 2.67 & \\
\hline & & & 0.93 \\
\hline no & 56 & 2.59 & \\
\hline Functioning adenomas: yes & 73 & 3.13 & \\
\hline & & & 0.09 \\
\hline no & 48 & 1.93 & \\
\hline CT/MRI tumor size: microadenomas & 24 & 2.59 & \\
\hline Intrasellar macroadenomas & 27 & 2.63 & 0.27 \\
\hline intra- suprasellar macroadenomas & 34 & 1.91 & \\
\hline intra- supra- parasellar macroadenomas & 36 & 3.29 & \\
\hline Infiltration of surrounding tissues: yes & 45 & 3.73 & \\
\hline & & & 0.02 \\
\hline no & 76 & 2.03 & \\
\hline Infiltration of CS: yes & 18 & 5.61 & \\
\hline & & & 0.0005 \\
\hline No & 103 & 2.09 & \\
\hline
\end{tabular}

\section{Statistical analysis}

Computer-assisted data analysis was performed with a commercially available software (SPSS 6.0, SPSS Inc., Chicago, IL). The normal distribution of Ki-67LI values was verified by using normal Q-Q plots, with the Blom's method. The $\mathrm{X}^{2}$ ( 1 or $2 d f$, continuity correction) and ANOVA tests were used to identify the statistical significance of differences of $\mathrm{Ki}-67 \mathrm{LI}$ observed in relation to functioning vs non functioning adenomas, presence or not of pre-operative visual disturbances, neuroradiological and surgical extimated volume of tumor, surgical invasiveness, and infiltration of CS. Values are expressed as the mean \pm standard deviation (SD) of the mean; for each comparison, a $P$ value was obtained (significance, $\leq$ o.05).

\section{Results}

The overall mean Ki-67 LI 2.72\% \pm 2.49 (median 1.6; range 0-31). In 7 patients the LI was $\geq 10: 2 \mathrm{ACTH}, 2 \mathrm{GH}$, 2 PRL, and $1 \mathrm{GH}-\mathrm{PRL}$ secreting adenomas; 5 out 7 were infiltrating, 4 of which were CS-infiltrating. In all cases there was not present any histological finding of pituitary carcinomas. We did not observe relevant differences of index in relation to age, sex, previous operations, presence of pre-operative visual disturbances, and functioning activity of tumor (Tab.1). Also the differences of index related to the neuroradiological and surgical extimated tumor size were not significant. The Ki-67 LI was $2.59 \% \pm 1.81$ in microadenomas, $2.63 \% \pm 3.45$ in intrasellar macroadenomas, $1.91 \% \pm 2.11$ in intra-suprasellar macroadenomas, and $3.29 \% \pm 5.45$ in intra-supra-parasellar macroadenomas $(\mathrm{p}=0.27)$.
Invasive adenomas has a $\mathrm{Ki}-67 \mathrm{LI}$ of $3.73 \pm 5.13 \%$ versus $2.03 \% \pm 2.41$ of non-invasive ones $(p=0.02)$; it was $5.61 \% \pm 7.19$ in CS-inffltrating adenomas and $2.09 \% \pm$ 2.37 in CS-non-inffltrating ones ( $\mathrm{p}=0.0005)$.

\section{Discussion}

Pituitary tumors are usually classified in microadenomas and macroadenomas $[10,11]$. In the first group the tumor consists of a well circumscribed nodule smaller than 10 $\mathrm{mm}$ in diameter [9], whereas macroadenomas produce enlargement of the contour of sella turcica $[10,11]$. Jules Hardy [10] proposed a schematic radiological classification of anterior pituitary adenomas as outlined by axial and coronal views of CT scan, today appliable to MRI. He divided pituitary tumors in "enclosed" (intrasellar adenomas) and "invasive" (intrasellar and intra-extrasellar adenomas). Enclosed adenomas are subdivided in Grade o (microadenomas). Grade I (macroadenoma with slight lowering of the floor), and Grade II (macroadenoma enlarging the sella, with intact floor). Invasive adenomas are subdivided in Grade III (macroadenomas eroding the floor) and Grade IV (macroadenoma destroying the floor).

Pituitary adenomas may be associated with a suprasellar extension, as well outlined by coronal CT scan and coronal and sagittal MR images. Hardy [10] classified them in five types: A) tumor bulging into the chiasmatic cistern; B) tumor reaching the anterior third ventricle; C) huge suprasellar extension filling entirely the third ventricle; D) parasellar extension into the temporal, frontal, or 
posterior fossa; and E) lateral expansion towards the cavernous sinus.

In order to simplify these classifications and to reduce the number of subgroups for correlations with Ki-67 LI values, we preferred to subdivide the tumors of our series into microadenomas, intrasellar macroadenomas, intrasuprasellar macroadenomas, and intra-supra-parasellar adenomas, including in the last group also pituitary adenomas infiltrating the wall of cavernous sinus.

The incidence of infiltration among anterior pituitary adenomas varies among the different subtytpes [26,31], also in relation to the criteria used to assess it. An infiltrating behaviour has been demonstrated surgically in about $35 \%$ and histologically (microscopic infiltration of dura mater) in about $90 \%$ of pituitary adenomas $[1,2,4-$ $6,12,15,16,18,20,25-27,30]$. It seems reasonable that the most reliable criterion of infiltration, with clinical and prognostic usefulness, is the impression of surgeon during operations [30].

Several cell cycle-specific nuclear antigens have been recognized with various immunohistochemical methods, allowing a reliable evaluation of tumor growth fraction. In particular, $\mathrm{Ki}-67$ is a nuclear antigen nowadays simply recognized by monoclonal antibody MIB-1 [21], typically expressed in proliferating cells during the $G_{1}, S, G_{2}$, and $M$ phases of the cell-cycle $[17,21,22,24,29,21,34]$. It turned out to be useful in a number of human neoplasms $[3,8,13,33]$, providing information about cellular proliferation rate and, thus, about long-term prognosis. It revealed to be a practical method that can be used in the routine histological evaluation of brain tumors and, also, of anterior pituitary adenomas. A high growth fraction expressed by a high Ki-67 LI should suggest a high proliferative rate and, thus, tight clinical-radiological follow-up, in relation to possible post-operative relapse of adenoma [14].

Up to date, only few Authors reported limited experiences regarding the evaluation of anterior pituitary adenoma growth fraction based on the expression of the Ki-67 antigen, both using formalin-fixed tissue and in vitro cell culture $[1,2,5,6,17-19,28,30]$. In particular, in a series of 70 anterior pituitary adenomas and of 7 carcinomas, Thapar et al [30] reported mean MIB-1 values of $1.37 \%$ in non-invasive adenomas, of $4.66 \%$ in invasive adenomas, and of $11.91 \%$ in pituitary carcinomas $(\mathrm{p}<0.01)$. Analogously, in our series LI was $2.03 \% \pm 2.41$ in non-infiltrating and $3.73 \% \pm 5.13$ in infiltrating adenomas $(\mathrm{p}=0.02)$; moreover, we observed a mean MIB-1 value of $5.61 \% \pm$ 7.19 in CS-infiltrating versus $2.09 \% \pm 2.37$ in CS-non-infiltrating adenomas $(p=0.0005)$. In relation to the frequency distribution of Ki-67 LIs in normal pituitary glands, in non-invasive pituitary adenomas, in invasive adenomas, and in pituitary carcinomas, Thapar et al [30] established a value of $3 \%$ as the threshold LI for distinguishing non-invasive from invasive anterior pituitary adenomas.

With te aim to establish a correlation between the growth fraction of pituitary adenomas and their neuroradiological and surgical extimated tumor size, we evaluated the Ki67 LI by means te monoclonal antibody MIB-1 in 121 patients. As summarized in table 1, the values of mean index were similar among microadenomas, intrasellar macroadenomas, and intra-suprasellar macroadenomas. The mean LI of intra-supra-parasellar macroadenomas (3.29\%) was higher than others subgroups and than the overall mean value (2.72\%); this difference was not statistically significant $(\mathrm{p}=0.27)$ and presumably reflects the higher incidence of invasive tumors among intra-supra-parasellar adenomas. Therefore, with the exception of invasive adenomas, the different tumor size of pituitary adenoma seems to be correlated to the time of growth rather than to a different growth fraction

\section{Conclusion}

The evaluation of growth fraction of pituitary tumors, identified by the Ki-67 nuclear antigen detected with the MIB-1 monoclonal antibody, presumably gives further information about their infiltrative behaviour. In our series of 121 cases, the analysis of proliferative rate seems to exclude a definite correlation between the mean value of Ki67 LI and the neuroradiological and surgical extimated tumor size of anterior pituitary adenomas.

\section{References}

I. Asano K, Kubo O, Tajika Y, Huang MC, Takakura K: The relationship between cell proliferation and secretory activity in pituitary adenomas. A review of 63 cases. No To Shinkei 1996, 48:543-549

2. Atkin SL, Green VL, Hipkin LJ, Landolt AM, Foy PM, Jeffreys RV, et al: A comparison of proliferation indices in human anterior pituitary adenomas using formalin-fixed tissue and in vitro cell culture. J Neurosurg 1997, 87:85-88

3. Brown DC, Gatter KC: Monoclonal antibody Ki-67: its use in histopathology. Histopathology 1990, I7:489-503

4. Buchfelder M, Fahlbusch R, Adams EF, Kiesewetter F, Thierauf P: Proliferation parameters for pituitary adenomas. Acta Neurochir Suppl (Wien) 1996, 65:18-21

5. Daita $G$, Yonemasu $Y$ : Dural invasion and proliferative potential of pituitary adenomas. Neurol Med Chir 1996, 36:2 I I-2 I 4

6. Ekramullah SM, Saitoh Y, Arita N, Ohnishi T, Hayakawa T: The correlation of $\mathrm{Ki}-67$ staining indices with tumour doubling times in regrowing non-functioning pituitary adenomas. Acta Neurochir (Wien) 1996, I38:| 449-1455

7. Gandour-Edwards R, Kapadia SB, Janecka IP, Martinez AJ, Barnes L: Biologic markers of invasive pituitary adenomas involving the sphenoid sinus. Mod Pathol 1995, 8:160-164

8. Hall PA, Woods AL: Immunohistochemical markers of cellular proliferation: achievements, problems, and prospects. Cell Tissue Kinet 1990, 23:505-522

9. Hardy J: Microsurgery of hypersecreting pituitary microadenomas. Ann Endocrinol 1971195-196 
10. Hardy ]: Transsphenoidal surgery of hypersecreting pituitary tumors. In: Diagnosis and treatment of pituitary tumors. PO Kohler, GT Ross, Eds. Excerpta Medica, American Elsevier, 1973179-194

II. Hardy J: Transsphenoidal microsurgical treatment of pituitary tumors. In: Recent Advances in the Diagnosis and Treatment of Pituitary Tumors. J Linfoot, Ed. Raven Press, 1979375-388

12. Henderson WR: The pituitary adenomata. A follow-up study of the surgical results in 338 cases (Dr. Harvey Cushing's series). Br J Surg 1939, 26:8| |-92 |

13. Hops NJ, Bremm J, Bohl J, Perneczky A: Image analysis of proliferating cells in tumors of the human nervous system: an immunohistological study with the monoclonal antibody Ki-67. Neurosurgery 1994, 35:917-923

14. Hsu DW, Hakim F, Biller BMK, De La Monte S, Zervas NT, Klibanski $\mathrm{A}$, et al: Significance of proliferating cell nuclear antigen index in predicting pituitary adenoma recurrence. J Neurosurg 1993, 78:753-761

15. Jefferson G: Extrasellar extension of pituitary adenomas. Proc $R$ Soc Med 1940, 33:433-458

16. Jefferson G: The invasive adenomas of the anterior pituitary, ed 2. Springfield, II I: Charles C. Thomas, 197256-60

17. Knosp E, Kitz K, Perneczky A: Proliferation activity in pituitary adenomas: measurement by monoclonal antibody Ki-67. Neurosurgery 1989, 25:927-930

18. Knosp E, Kitz K, Steiner E, Matula C: Pituitary adenomas with parasellar invasion. Acta Neurochir Suppl (Wien) I99I, 53:65-7I

19. Landolt AM, Shibata T, Kleihues P: Growth rate of human pituitary adenomas. I Neurosurg 1987, 67:803-806

20. Martins AN, Hayes G], Kempe LG: Invasive pituitary adenomas. J Neurosurg 1965, 22:268-276

21. McCormick D, Chong $\mathrm{H}$, Hobbs C: Detection of the Ki-67 antigen in fixed and wax-embebbed sections with the monoclonal antibody MIB-I. Histopathology 1993, 22:355-360

22. Morimura T, Kitz K, Stein H: Determination of proliferative activities in human brain tumor specimens: a comparison of three methods. J Neurooncol I991, 10:I-II

23. Nagashima T, Murovic JA, Hoshino T, Wilson CB, DeArmond SJ: The proliferative potential of human pituitary tumors in situ. $J$ Neurosurg 1986, 64:588-593

24. Parkins CS, Darling JL, Gill SS: Cell proliferation in serial biopsies through malignant brain tumors: measurement using Ki-67 antibody labelling. Br J Neurosurg |99|, 5:289-298

25. Pernicone PJ, Scheithauer BW: Invasive pituitary adenomas and pituitary carcinomas, in Loyd RV (ed): Surgical Pathology of the Pituitary Gland. Philadelphia, W.B. Saunders, Co., 1993121-136

26. Scheithauer BW, Kovacs KT, Laws ER Jr, Randall RV: Pathology of invasive pituitary tumors with special reference to functional classification. J Neurosurg 1986, 65:733-744

27. Selman WR, Laws ER, Scheithauer BW, Carpenter SM: The occurrence of dural invasion in pituitary adenomas. J Neurosurg 1986, 64:402-407

28. Shibuya M, Saito F, Miwa T, Davis RL, Wilson CB, Hoshino T: Histochemical study of pituitary adenomas with $\mathrm{Ki}-67$ and antiDNA polymerase alpha monoclonal antibodies, bromodeoxyuridine labeling, and nucleolar organizer region counts. Acta Neuropathol (Berl) 1992, 84:178-183

29. Shiraishi T: Cell kinetic analysis of brain tumors using the monoclonal antibody $\mathrm{Ki}-67$ : in vitro and in situ study. Acta Med Okayama 1990, 44:197-201

30. Thapar K, Kovacs K, Scheithauer BW, Stefaneanu L, Horvath E, Pernicone PJ, et al: Proliferative activity and invasiveness among pituitary adenomas and carcinomas: an analysis using the MIB-I antibody. Neurosurgery 1996, 38:99-107

31. Trumble HC: Pituitary tumours. Observations on large tumours which have spread widely beyond the confines of the sella turcica. Br J Surg I95I, 39:7-24

32. Tsanaclis AM, Robert F, Michaud J: The cycling pool of cells within human brain tumors: in situ cytokinetics using the monoclonal antibody Ki-67. Can J Neurol Sci 1991, 18:12-17

33. Wintzer HO, Zipfel I, Schulte-Monting J, Hellerich U, von Kleist S: Ki67 immunostaining in human breast tumours and its relationship to prognosis. Cancer 1990, 67:42I-428

34. Zuber P, Hamou MF, de Tribolet N: Identification of proliferating cells in humas gliomasusing the monoclonal antibody Ki-67. Neurosurgery 1988, 22:364-368
Publish with BioMed Central and every scientist can read your work free of charge

"BioMedcentral will be the most significant development for disseminating the results of biomedical research in our lifetime."

$$
\text { Paul Nurse, Director-General, Imperial Cancer Research Fund }
$$

Publish with BMC and your research papers will be:

- available free of charge to the entire biomedical community

- peer reviewed and published immediately upon acceptance

- cited in PubMed and archived on PubMed Central

- yours - you keep the copyright 